\title{
PENGARUH KOMITMEN MANAJEMEN, PERILAKU POSITIF TENAGA KESEHATAN DAN DUKUNGAN DINKES TERHADAP KUALITAS LAYANAN PADA UPTD PUSKESMAS DI KABUPATEN BARITO SELATAN PROVINSI KALIMANTAN TENGAH
}

\author{
Setia Lestari \\ Sekolah Tinggi Ilmu Ekonomi Pancasetia Banjarmasin \\ Jl. Ahmad Yani Km. 5.5 Banjarmasin \\ setialestari88@gmail.com
}

\begin{abstract}
Abstrak: Setia Lestari, Npm.1911.32202.5182, Pengaruh Komitmen Manajemen, Perilaku Positif Tenaga Kesehatan Dan Dukungan Dinkes Terhadap Kualitas Layanan Pada UPTD Puskesmas Di Kabupaten Barito Selatan Provinsi Kalimantan Tengah, Dibawah Bimbingan Lanny Purnama Kosasi Dan H.M. Zaid Abdurakhman, 2021. Tujuan penelitian ini adalah Untuk mengetahui dan menganalisi pengaruh komitmen manajemen, perilaku positif tenaga kesehatan dan dukungan Dinkes berpengaruh secara simultan terhadap kualitas layanan, Untuk mengetahui dan menganalisi pengaruh komitmen manajemen, perilaku positif tenaga kesehatan dan dukungan Dinkes berpengaruh secara parsial terhadap kualitas layanan dan untuk mengetahui dan menganalisis diantara komitmen manajemen, perilaku positif tenaga kesehatan dan dukungan Dinkes yang berpengaruh dominan terhadap kualitas layanan pada UPTD Puskesmas di Kabupaten Barito Selatan Provinsi Kalimantan Tengah.Populasi penelitian adalah tenaga kesehatan di UPTD Puskesmas di Kabupaten Barito Selatan Provinsi Kalimantan Tengah 685 sedangkan sampel 87 responden dengan analisis regresi berganda. Hasi uji hipotesis pertama diketahui bahwa komitmen manajemen, perilaku positif tenaga kesehatan dan dukungan Dinkes berpengaruh signfikan secara simultan terhadap kualitas layanan, uji hipotesis kedua diketahui bahwa komitmen manajemen, perilaku positif tenaga kesehatan dan dukungan Dinkes berpengaruh signfikan secara parsial terhadap kualitas layanan dan hasi uji hipotesis ketiga diketahui bahwa komitmen manajemen, berpengaruh signfikan secara dominan terhadap kualitas layanan pada UPTD Puskesmas di Kabupaten Barito Selatan Provinsi Kalimantan Tengah.
\end{abstract}

\section{Kata Kunci : Komitmen Manajemen, Perilaku Positif, Dukungan Dinkes dan Kualitas Layanan}

\begin{abstract}
Setia Lestari, Npm.1911.32202.5182, The Effect Of Management Commitment, Positive Behavior Of Health Personnel And Dhopping Support On Quality Of Service At The UPTD Puskesmas In Barito Selatan District Province Kalimantan, Tengah. Under The Guidance Lanny Purnama Kosasi And Zaid Abdurakhman, 2021. The purpose of this study was to determine and analyze the effect of management commitment, positive behavior of health workers and the support of the Health Office simultaneously influence the quality of service, to determine and analyze the effect of management commitment, positive behavior of health workers and support from the Health Office partially affect service quality and to determine and analyze between management commitment, positive behavior of health workers and support from the Health Office which have a dominant influence on service quality at UPTD Puskesmas in South Barito Regency, Central Kalimantan Province. The study population was health workers at the UPTD Puskesmas in South Barito Regency, Central Kalimantan Province, 685 while the sample was 87 respondents with multiple regression analysis. The results of the first hypothesis test are known that management commitment, positive behavior of health workers and support from the Health Office have a significant simultaneous effect on service quality, the second hypothesis test is known that management commitment, positive behavior of health workers and support from the Health Office have a partially significant effect on service quality and the results of hypothesis testing Third, it is known that management commitment has a dominant significant effect on service quality at the UPTD Puskesmas in South Barito Regency, Central Kalimantan Province.
\end{abstract}

Keywords: Management Commitment, Positive Behavior, Health Office Support and Service Quality 


\section{BAB I \\ PENDAHULUAN \\ 1.1. Latar Belakang Masalah}

Puskesmas sebagai sarana atau subsistem untuk memenuhi segala pelayanan kesehatan, juga merupakan suatu industri jasa yang berfungsi untuk memenuhi kebutuhan primer manusia, baik berbagai individu maupun masyarakat secara keseluruhan dan untuk meningkatkan hajat hidup yang utama, yaitu kesehatan. Semakin banyaknya orang membutuhkan pelayanan kesehatan, maka rumah sakit dituntut untuk semakin meningkatkan kualitas layanan sehingga puskesmas dapat memberikan kepuasan kepada pasien. Pertimbangan pada pandangan pasien yang berfokus pada tingkat kepuasan, maka intensitas peningkatan layanan harus selalu ditingkatkan agar dapat mendorong masyarakat untuk meraih pelayanan kesehatan secara baik dan dapat memahami kebutuhan pasien dengan tepat, sehingga kepuasan pasien dapat dicapai. Kepuasan pasien adalah tingkat kesesuaian antara produk dan/atau jasa pelayanan yang diinginkan dengan kenyataan yang diterima. Tingkat kesesuaian tersebut adalah hasil penelitian yang dilakukan oleh masyarakat berdasarkan pada pengetahuan dan pengalamannya. Kepuasan pasien sangat ditentukan oleh kualitas jasa yang di kehendaki sehingga jaminan kualitas menjadi prioritas utama dan di jadikan tolak ukur keunggulan daya saing puskesmas. Guna menunjang aktivitas kesehatan tersebut diperlukan adanya komitmen yang kuat dari pihak manajemen dari lembaga kesehatan dalam hal ini puskesmas dalam membangun dan mengembangkan pelayanan kesehatan karena hal tersebut merupakan hak dasar masyarakat yang harus dipenuhi dalam pembangunan kesehatan hal ini sejalan dengan UU No. 36 tahun 2009 pasal 1 yang menyebutkan kesehatan merupakan hak azazi manusia dan salah satu unsur kesejahteraan yang harus diwujudkan sesuai dengan cita-cita bangsa Indonesia yang kemudian tercantum pula pada Undang-Undang Dasar 1945 pasal 34 ayat 3 yang menyebutkan negara bertanggungjawab menyediakan fasilitas pelayanan kesehatan dan fasilitas pelayanan umum yang layak, salah satu fasilitasnya adalah rumah sakit dan puskesmas. Untuk itulah komitmen manajemen suatu lembaga kesehatan perlu ditingkatkan. Menurut Rikwan (2011:97) menjelaskan komitmen manajemen adalah manajemen (pimpinan dan segenap jajarannya) memiliki perjanjian (keterkaitan) untuk melakukan sesuatu dan dala pembahasan ini sesuatu itu adalah perubahan yang telah disepakati bersama untuk dijalankan. Selain itu menurut Schneider \& Bowen, 1992; Lovelock, 1985; dalam Tavitiyaman, 2010:89) menerangkan komitmen manajemen tidak hanya terlihat dari kepercayaan individu saja, akan tetapi juga dari tindakannya setiap karyawan harus mengerti filofosi organisasi, mengetahui peran dan tanggung jawab, serta termotivasi untuk berperilaku melayani. Di samping itu manajemen puskesmas pun perlu adanya personel yang mempunyai perilaku yang baik dalam bekerja guna menunjang kualitas dalam pelayanan. Perilaku seseorang di dalam organisasi berkaitan dengan bagaimana orang bertindak dan bereaksi dalam semua jenis organisasi. Dalam kehidupan organisasi, orang dipekerjakan, dididik dan dilatih, diberi informasi, dilindungi, dan dikembangkan. Dengan kata lain, maka perilaku organisasi adalah bagaimana orang berperilaku di dalam suatu organisasi. Prilaku seseorang dalam organisasi adalah suatu studi yang menyangkut aspek-aspek tingkah laku manusia dalam suatu kelompok tertentu. Hal ini meliputi aspek yang ditimbulkan oleh pengaruh organisasi terhadap manusia demikian pula aspek yang ditimbulkan dari pengaruh manusia terhadap organisasi. Tujuan praktis dari penelaan studi ini adalah untuk mendeterminasi bagaimanakah perilaku manusia itu mempengaruhi usaha pencapaian tujuan-tujuan organisasi. Menurut Stephen P. Robins (2010:71), perilaku pegawai adalah bidang yang menyelidiki pengaruh yang di timbulkan oleh individu, kelompok, dan struktur terhadap perilaku (manusia) didalam organisasi dengan tujuan menerapkan pengetahuan untuk meningkatkan efektivitas organisasi sedangkan menurut Irmin (2011:132) menjelaskan tentang perilaku positif adalah perilaku seseorang yang cenderng bermanfaat baik bagi diri sendiri dan orang lain selain itu juga perilaku yang sesuai dengan nilai dan norma sosial yang berlaku dalam masyarakat. Dengan tertanamnya perilaku kerja yang positip dari pegawai, maka sikap mereka akan cenderung memberikan manfaat bagi diri sendiri maupun orang lain. Perilaku positif ini banyak disukai oleh manusia lainnya. Karena sejatinya setiap tindakan perilaku positif dapat membawa kesuksesan apabila dilakukan secara konstan dan terus menerus. Faktor dukungan dari Dinas Kesehatan pun dapat mempengaruhi akan kualitas dari kinerja puskesmas. Dinas Kesehatan (Dinkes) merupakan salah satu Satuan Kerja Pemerintah Daerah (SKPD) dilingkungan pemerintah daerah yang bertanggung jawab dalam bidang pembangunan kesehatan,fungsi Dinkes sebagai lembaga dinas 
teknis yang mempunyai tugas pokok melaksanakan sebagian urusan pemerintahan daerah di bidang kesehatan berdasarkan asas otonomi dan membantu melaksanakan tugas teknis operasional di bidang kesehatan yang meliputi pengembangan dan pembinaan pelayanan kesehatan, pencegahan pemberantasan penyakit menular dan penyehatan lingkungan, kesehatan keluarga, pelayanan farmasi dan pengawasan makanan dan minuman serta pembinaan program kesehatan lainnya. Menurut Mulia (2012:110) menjelaskan peranan atau dukung Dinskes dalam bidang kesehatan adalah sebagai regulator atau memiliki fungsi rangkap sebagai regulator sistem kesehatan sekaligus sebagai operator pelayanan kesehatan. Sejalan dengan uraian tersebut di obyek penelitian pada Puskesmas yang ada di Kabupaten Barito Selatan Provinsi Kalimantan Tengah selama ini pada penelitian awal peneliti diketahui masih terdapat sebagian puskesmas dalam menjalankan tugasnya belum optimal, pihak manajemen puskesmas terkesan kurang mempunyai komitmen yang kuat dalam memberikan pelayanan yang baik terhadap masyarakat, hal ini kerap terlihat dari terjadi masalah di lapangan dimana saat pasien berobat pihak manajemen puskesmas belum dapat memberikan pelayanan yang cepat, bahkan terkesan lambat dalam melayani ditambah lagi fasilitas yang kurang lengkap. Selain itu kasus lain yang kerap kali didapati saat dipuskesmas adalah adanya perilaku tenaga kesehatan yang kurang baik, seperti dalam saaat tugas atau lagi memberikan pelayanan kepada pasien para petugas kadang asik berbicara, sehingga kerap pasien merasa kurang nyaman saat melakukan pemeriksaan kesehatan, ditambah lagi masih ada beberapa tenaga kesahatan yang kurang ramah dalam memberikan pelayanan kesehatan. Kadang juga terjadi diagnosis dari dokter tanpa ada pemeriksaan yang lebih mendalam tanpa melakukan tindakan medik sesuai standar pelayanan medik. Guna meningkatkan pelayanan tersebut tidak lepas pula peran dari Dinas Kesehatan sebagai regulator atau memiliki fungsi rangkap sebagai regulator sistem kesehatan sekaligus sebagai operator pelayanan kesehatan. Kebijakan Dinas Kesehatan bagi kemajuan pelayanan puskesmas sangat berperan penting, namun selama ini dirasakan peran Dinas Kesehatan terkesan kurang optimal, hal ini terlihat dari terbatasnya sarana dan prasarana kesehatan yang di miliki puskesmas di Kabupaten Barito Selatan Provinsi Kalimantan Tengah sehingga petugas kesehatan dalam memberikan pelayanan kesehatan pun menjadi terbatas dan sering terhambat yang disebabkan oleh peralatan kesehatan yang kurang lengkap. Selain itu masih terdapat permasalahan lain di puskesmas yakni tidak meratanya pemenuhan tenaga kesehatan dan masih terdapat puskesmas kekurangan personel hal ini terlihat dari masih adanya pegawai kesehatan di Kabupaten Barito Selatan Provinsi Kalimantan Tengah yang merangkap-rangkap pekerjaan sehingga berdapak terhadap kurang berjalan optimalnya pelayanan yang diberikan. Sejalan dengan uraian tersebut materi permasalahan menitik beratkan pada faktor komitmen manajemen, perilaku positif tenaga kesehatan dan dukungan Dinkes yang berdampak terhadap kualitas pelayanan dipuskesmas, sehubungan dengan hal tersebut, mana peneliti tertarik untuk mengangkat masalah tersebut kedalam sebuah penelitian dengan materi judul

Pengaruh Komitmen Manajemen, Perilaku Positif Tenaga Kesehatan Dan Dukungan Dinkes Terhadap Kualitas Layanan Pada UPTD Puskesmas di Kabupaten Barito Selatan Provinsi Kalimantan Tengah.

\subsection{Rumusan Masalah}

Berdasarkan uraian latar belakang di atas, maka rumusan masalah dalam penelitian ini:

1. Apakah komitmen manajemen, perilaku positif tenaga kesehatan dan dukungan Dinkes berpengaruh signfikan secara simultan terhadap kualitas layanan pada UPTD Puskesmas di Kabupaten Barito Selatan Provinsi Kalimantan Tengah?

2. Apakah komitmen manajemen, perilaku positif tenaga kesehatan dan dukungan Dinkes berpengaruh signfikan secara parsial terhadap kualitas layanan pada UPTD Puskesmas di Kabupaten Barito Selatan Provinsi Kalimantan Tengah?

3. Diantara komitmen manajemen, perilaku positif tenaga kesehatan dan dukungan Dinkes manakah yang berpengaruh dominan terhadap kualitas layanan pada UPTD Puskesmas di Kabupaten Barito Selatan Provinsi Kalimantan Tengah?

\subsection{Landasan Teori}

\section{BAB II}

TINJAUAN PUSTAKA

\subsubsection{Komitmen Manajemen}

Menurut Gibson, Ivancevich, dan Donnely, (1982) dalam Abomaleh \& Zahari. (2015:34) menerankan komitmen (ketertarikan) adalah "rasa identifikasi, keterlibatan, dan loyalitas atau kesetiaan yang dinyatakan oleh seseorang terhadap perusahaan". Menurut Robbins, (2010:84) menjelaskan 
komitmen adalah derajat sejauh mana seorang pegawai memihak suatu organisasi tertentu dengan tujuan-tujuannya, dan berminat untuk mempertahankan keanggotaan dalam organisasi itu. Menurut Porter dan Smith, (1997) dalam Setyowati (2010:76) menjelaskan komitmen adalah sifat hubungan seorang individu dengan seorang individu dengan organisasi yang memungkinkan seseorang mempunyai komitmen yang tinggi dengtan memperlihatkan keinginan yang kuat untuk tetap menjadi pegawai organisasi yang bersangkutan, kesediaan utk berusaha sebaik mungkin demi kepentingan organisasi tersebut, dan kepercayaan akan dan penerimaan yang kuat terhadap nilai-nilai dan tujuan organisasi. Mowday (2005) dalam Syarif (2018:31) menjelaskan komitmen manajemen didefinisikan tingkat kekerapan identifikasi dan keterikatan individu terhadap organisasi yang dimasukinya, dimana karakteristik komitmen organisasional antara lain adalah loyalitas seseorang terhadap organisasi, kemauan untuk mempergunakan usaha atas nama organisasi, kesuaian antara tujuan seseorang dengan tujuan organisasi. Selain itu menurut Nadirsyah (2011:324) menjelaskan komitmen manajemen adalah suatu keyakinan dan dukungan yang kuat dari manajemen untuk melakukan, menjalankann dan mengimplementasikan suatu kebijakan yang ditetapkan secara bersama sehingga tujuan atas diterapkannya kebijakan tersebut dapat dicapai. Indikator komitmen manajemen menurut Nurkhamid (2012:211) menjelaskan, yaitu manajemen memiliki komitmen untuk mengalokasikan sumberdaya meliputi waktu, orang, uang, menugaskan staf dan devisi/departemen dalam organisasi untuk melakukan evaluasi terhadap kinerja suatu program, pengumpulan data yang relevan dan reliabel sehingga dapat digunakan untuk menilai kinerja organisasi serta menggunakan tolak ukur mengevaluasi kinerja organisasi. Menurut Dominic Cooper (1997) dalam Soeminto (2013:231) menyatakan tentang komitmen manajemen adalah tanggung jawab manajemen perusahaan untuk menetapkan sasaran objective yang strategis dan sasaran mutu manajemen harus memiliki komitmen dalam penerapannya.

Tavitiyaman, (2010:93) membedakan faktor-faktor yang mempengaruhi komitmen organisasi/manajemen menjadi empat kategori yaitu karakter personal, karakteristik pekerjaan, karakteristik structural, pengalaman kerja
David (1998) dalam Sopiah, (2012:163) mengemukakan empat faktor yang mempengaruhi komitmen manajemen/organisasi yaitu:

a. Faktor personal : usia, jenis kelamin, singkat pendidikan, pengalamn kerja, kepribadian dan lain-lain.

b. Karakteristik pekerjaan : lingkup jabatan, tantangan dalam pekerjaan, konflik pekerjaan, tingkat kesulitan dalam pekerjaan, dan lain-lain.

c. Karakteristik struktur : besar kecilnya organisasi, bentuk organisasi dan kehadiran serikat pekerjaan.

d. Pengalaman kerja

\subsubsection{Perilaku Positif Tenaga Kesehatan}

Sopiah (2012:190) menjelaskan secara definisi perilaku adalah perasaan, pikiran, dan kecenderungan seseorang yang relatif permanen mengenal aspek-aspek tertentu dalam lingkungannya. Komponen-komponen sikap terdiri dari pengetahuan (kognitif), perasaan-perasaan (afektif), dan kecenderungan untuk bertindak (psikomotorik). Menurut Okviana, (2015:214) menerangkan tentang perilaku adalah segenap manifestasi hayati individu dalam berinteraksi dengan lingkungan, mulai dari perilaku yang paling nampak sampai yang tidak tampak, dari yang dirasakan sampai paling yang tidak dirasakan. Menurut Notoatmojo, (2010:112) menjelaskan perilaku merupakan hasil daripada segala macam pengalaman serta interaksi manusia dengan lingkunganya yang terwujud dalam bentuk pengetahuan, sikap dan tindakan. Perilaku merupakan respon/reaksi seorang individu terhadap stimulusyang berasal dari luar maupun dari dalam dirinya. Sedangkan menurut Wawan (2011:213) perilaku merupakan suatu tindakan yang dapat diamati dan mempunyai frekuensi spesifik, durasi dan tujuan baik disadari maupun tidak. Stephen P. Robins (2001) dalam Okviana, (2015:21) menjelaskan perilaku pegawai adalah bidang yang menyelidiki pengaruh yang di timbulkan oleh individu, kelompok, dan struktur terhadap perilaku (manusia) didalam organisasi dengan tujuan menerapkan pengetahuan untuk meningkatkan efektivitas organisasi. Darmawan (2010:94) menjelaskan perilaku positip adalah sikap seseorang yang sesuai dengan nilai-nilai dan norma-norma kehidupan yang berlaku dimasyarakat. Menurut Irmin (2011:132) menjelaskan tentang perilaku positif adalah perilaku seseorang yang cenderng bermanfaat baik bagi diri sendiri dan orang lain selain itu juga perilaku yang sesuai dengan nilai dan norma sosial yang berlaku dalam masyarakat. Simanjuntak 
(2013:67) menjelaskan perilaku positif adalah perilaku yang ditunjukkan oleh seeorang atau anggota organisasi yang merupakan perilaku yang produktif dan dapat menunjang pencapaian dari tujuan organisasi. Menurut Bansal et al, (2001) dalam Ancok (2012:78) menjelaskan tentang perilaku positif karyawan adalah tidakan konstruktif di pihak pegawai atas kepentingan perusahaan, pegawai lain dan konsumen. Hari (2013:215) menjelaskan perilaku positif adalah perilaku yang cenderung memberikan manfaat bagi diri sendiri maupun orang lain. Perilaku positif ini banyak disukai oleh manusia lainnya. Karena sejatinya setiap tindakan perilaku positif dapat membawa kesuksesan apabila dilakukan secara konstan dan terus menerus.

Menurut Ikwanuddin (2011:133) menjelaskan indikator berperilaku positif, diantaranya adalah selalu berpikir positif, selalu semangat, selalu berdisiplin dalam bekerja, selalu berusaha memberikan yang terbaik dalam bekerja, selalu mempunyai motivasi kerja yang tinggi, mempunyai percaya diri yang baik dalam bekerja, selalu menjauhi hal-hal yang tidak baik dalam bekerja dan mempunyai loyalitas dan integritas terhadap bidang pekerjaan

Menurut Mariam (2013:87) menjelaskan indikator perilaku positif seseorang adalah disiplin dalam bekerja, suka bekerja keras dan ulet, jujur dalam bekerja, mempunyai tanggungjawab yang tinggi terhadap pekerjaan, mempunyai toleransi yang tinggi dan mempunyai kekuatan rohani yang baik

\subsubsection{Dukungan Dinkes}

Pelayanan kesehatan merupakan hak dasar masyarakat yang harus dipenuhi dalam pembangunan kesehatan. Banyak permasalahan kesehatan yang ada di indonesia yang mengenai pelayanan kesehatan. Guna mendukung keberhasilan progran kesehatan tersebut perlu sekali dukungan yang kuat dari instansi terkait dalam hal ini Dinas Kesehatan. Menurut Menurut Azrul Azwar (2016:16) menjelaskan untuk mengatasi berbagai permasalahan kesehatan, adapun kebijakan pemerintah dalam menangani masalah pelayanan kesehatan :

1. Peningkatan upaya pemeliharaan, pelindungan, dan peningkatan derajat kesehatan dan status gizi terutama bagi penduduk miskin dan kelompok rentan.

2. Peningkatan upaya pencegahan dan penyembuhan penyakit baik menular maupun tidak menular.

3. Peningkatan kualitas, keterjangkauan, dan pemerataan pelayanan kesehatan di fasilitas pelayanan kesehatan dasar dan rujukan terutama bagi keluarga miskin, kelompok rentan dan penduduk di daerah terpencil, perbatasan, rawan bencana dan konflik.

4. Peningkatan kualitas dan kuantitas tenaga kesehatan terutama untuk pelayanan kesehatan di daerah terpencil, tertinggal, dan perbatasan.

5. Penjaminan mutu, keamanan dan khasiat produk obat, kosmetik, produk komplemen, dan produk pangan yang beredar, serta mencegah masyarakat dari penyalahgunaan obat keras, narkotika, psikotropika, zat adiktif, dan bahan berbahaya lainnya.

6. Peningkatan promosi kesehatan dan pemberdayaan masyarakat dalam perilaku hidup bersih dan sehat.Meningkatkan Pemerataan dan Keterjangkauan Pelayanan Kesehatan

Dinas Kesehatan (Dinkes) merupakan salah satu Satuan Kerja Pemerintah Daerah (SKPD) dilingkungan pemerintah daerah yang bertanggung jawab dalam bidang pembangunan kesehatan,fungsi Dinkes sebagai lembaga dinas teknis yang mempunyai tugas pokok melaksanakan sebagian urusan pemerintahan daerah di bidang kesehatan berdasarkan asas otonomi dan membantu melaksanakan tugas teknis operasional di bidang kesehatan yang meliputi pengembangan dan pembinaan pelayanan kesehatan, pencegahan pemberantasan penyakit menular dan penyehatan lingkungan, kesehatan keluarga, pelayanan farmasi dan pengawasan makanan dan minuman serta pembinaan program kesehatan lainnya. Menurut Mulia (2012:110) menjelaskan peranan atau dukung Dinskes dalam bidang kesehatan adalah sebagai regulator atau memiliki fungsi rangkap sebagai regulator sistem kesehatan sekaligus sebagai operator pelayanan kesehatan. Menurut Heriawan (2012:25) menjelaskan dukungan Dinkes adalah suatu aktivitas dan kegiatan yang diberikan Dinas Kesehatan kepada instansi kesehatan baik itu rumah sakit maupun puskesmas baik itu dalam bentuk kebijakan, fasilitas maupun hal lain yang dapat menunjang kelancaran dan keberhasilan institusi kesehatan dalam menigkatan masyarakat yang sehat.

\subsubsection{Kualitas Layanan}

Pelayanan kegiatan yang bertujuan untuk memberikan atau aktivitas seseorang atau organisasi untuk memberikan kepuasan kepada masyarakat atau konsumen. Kashmir, (2011:75) menjelaskan pelayanan yang baik memungkinkan sebuah perusahaan memperkuat kesetiaan pelanggan dan meningkatkan pangsa pasar (market share), karena itu pelayanan yang baik menjadi 
penting dalam operasi perusahaan. Selain itu service adalah kegiatan yang dapat diidentifikasikan dan tidak berwujud dan merupakan tujuan penting dari suatu rencana transaksi, guna memberikan kepuasan kepada konsumen. Muchtarman, (2012:27) layanan hakikatnya adalah serangkaian kegiatan, karena ia merupakan proses. Sebagai proses, layanan berlangsung secara rutin dan berkesinambungan meliputi seluruh kehidupan organisasi dalam masyarakat.Tjiptono, (2011:36), mendefinisikan pelayanan adalah "suatu tindakan yang dilakukan untuk memenuhi kebutuhan orang lain yang tingkat kepuasan hanya dapat dirasakan oleh yang melayani maupun yang dilayani. Menurut Alma, (2012:90) mengemukakan pelayanan atau service adalah setiap kegiatan atau manfaat yang ditawarkan oleh suatu pihak kepada pihak lain dan pada dasarnya tidak berwujud dan tidak pula berakibat kepemilikian sesuatu dan produksinya dapat atau tidak dapat dikaitkan dengan suatu produk fisik. Menurut Siregar (2013:152) layanan adalah kegiatan pemberian jasa dari satu pihak kepada pihak lainnya. Pelayanan yang baik adalah pelayanan yang dilakukan secara ramah tamah, adil, cepat, tepat, dan etika yang baik sehingga memenuhi kebutuhan dan kepuasan bagi yang menerimanya. Menurut pendapat Rasyid, (2012:88) pelayanan dapat diartikan sebagai pemberian layanan (melayani) keperluan orang atau masyarakat yang mempunyai kepentingan pada organisasi itu sesuai dengan aturan pokok dan tata cara yang telah ditetapkan. Sebagaimana telah dikemukakan terdahulu bahwa pemerintah pada hakekatnya adalah pelayan masyarakat. Ia tidaklah diadakan untuk melayani dirinya sendiri tetapi untuk melayani masyarakat serta menciptakan kondisi yang memungkinkan setiap anggota masyarakat mengembangkan kemampuan dan kreativitas demi mencapai tujuan bersama. Hadipranata (2010:132) pelayanan adalah aktivitas tambahan di luar tigas pokok yang diberikan kepada konsumen atau pelanggan, nasabah dan sebagainya serta dirasakan baik sebagai penghargaan maupun penghormatan. Menurut Loomba (1973) dalam Hadipranata (2010:135) menjelaskan pelayanan kesehatan adalah sub sistem pelayanan kesehatan yang tujuan utamanya adalah pelayanan preventif (pencegahan) dan promotif (peningkatan kesehatan) dengan sasaran masyarakat. Menurut Levey (1999) dalam Rasyid, (2012:90) menerangkan pelayanan Kesehatan Adalah upaya yang diselenggarakan sendiri atau secara bersama-sama dalam suatu organisasi untuk memelihara dan meningkatkan kesehatan, mencegah, dan mencembuhkan penyakit serta memulihkan kesehatan perorangan, keluarga, kelompok, atau masyarakat. Menurut Azrul Azwar (2016:22) menjelaskan pelayanan kesehatan adalah setiap upaya diselenggarakan sendiri secara bersama-sama dalam suatu organisasi untuk memelihara dan meningkatkan kesehatan, mencegah dan menyembuhkan penyakit serta memulihkan kesehatan perorangan, keluarga, kelompok dan ataupun masyarakat.

Menurut Zeithhaml, Parasuraman \& Berry (dalam Hardiansyah 2011:46) untuk mengetahui kualitas pelayanan yang dirasakan secara nyata oleh konsumen, ada indikator kualitas pelayanan yang terletak pada lima dimensi kualitas pelayanan, yaitu:

1. Tangibles (berwujud), yaitu kualitas pelayanan berupa sarana fisik perkantoran, komputerisasi administrasi, ruang tunggu, tempat informasi.

2. Realibility (kehandalan), yaitu kemampuan dan keandalan untuk menyediakan pelayanan yang terpercaya.

3. Responsivess (ketanggapan), yaitu kesanggupan untuk membantu dan menyediakan pelayanan secara cepat dan tepat, serta tanggap terhadap keinginan konsumen.

4. Assurance (jaminan), yaitu kemampuan dan keramahan serta sopan santun pegawai dalam meyakinkan kepercayaan konsumen.

5. Emphaty (Empati), yaitu sikap tegas tetapi penuh perhatian dari pegawai terhadap konsumen.

Keputusan Menteri Pemberdayaan Aparatur Negara Pemerintah Nomor 96 Tahun 2012 pelaksanaan terhadap Kepmen Nomor KEP25/M.PAN/2/2009 tanggal 24 pebruari 2009 terdapat 14 indikator pelayanan sebagai berikut:

1. Prosedur pelayanan yaitu kemudahan tahap pelayanan yang diberikan kepada masyarakat.

2. Persyaratan pelayanan yaitu persyaratan teknis dan administratif yang diperlukan untuk mendapatkan pelayana sesuai dengan jenis pelayanannya.

3. Kejelasan petugas pelayanan yaitu keberadaan dan kepastian petugas yang memberikan pelayanan.

4. Kedisiplinan petugas pelayanan yaitu kesungguhan petugas dalam memberikan pelayanan terutama konsisten waktu kerja sesuai ketentuan yang berlaku.

5. Tanggungjawab petugas yaitu kejelasan wewenang dan tanggung jawab dalam penyelenggaraan dan penyelesaian pelayanan. 
6. Kemampuan petugas pelayanan yaitu tiingkat keahlian dan keterampilan yang dimiliki petugas dalam memberikan pelayanan.

7. Kecepatan pelayanan yaitu Target waktu pelayanan dapat diselesaikan dalam waktu yang ditentukan.

8. Keadilan dalam mendapatkan pelayanan yaitu pelaksanaan pelayanan dengan tidak membedakan golongan/stattus masyarakat yang dilayani.

9. Kesopanan dan keramahan petugas yaitu bentuk sikap dan perilaku petugas yang baik sopan dan ramah dalam memberikan pelayanan.

10. Kewajaran biaya pelayanan yaitu Keterjangkauan masyarakat terhadap besarnya biaya pelayanan.

11. Kepastian biaya pelayanan yaitu kesesuaian antara biaya yang dibayar dengan biaya yang ditetapkan.

12. Kepastian jadwal pelayanan yaitu yaitu disiplin terhadap pelaksanaan waktu pelayanan sesuai dengan ketentuan.

13. Kenyamanan lingkungan yaitu menyangkut kondisi sarana dan prasaran dapat diberikan dengan nyaman pada penerima layanan.

14. Keamanan pelayanan yaitu terjaminnya tingkat keamanan lingkungan unit penyelnggaraan pelayanan.

\section{BAB III}

\section{KERANGKA KONSEPTUAL DAN HIPOTESIS}

\subsection{Kerangka Konseptual}

Kerangka konseptual dalam penelitian ini di gambarkan sebagai berikut:

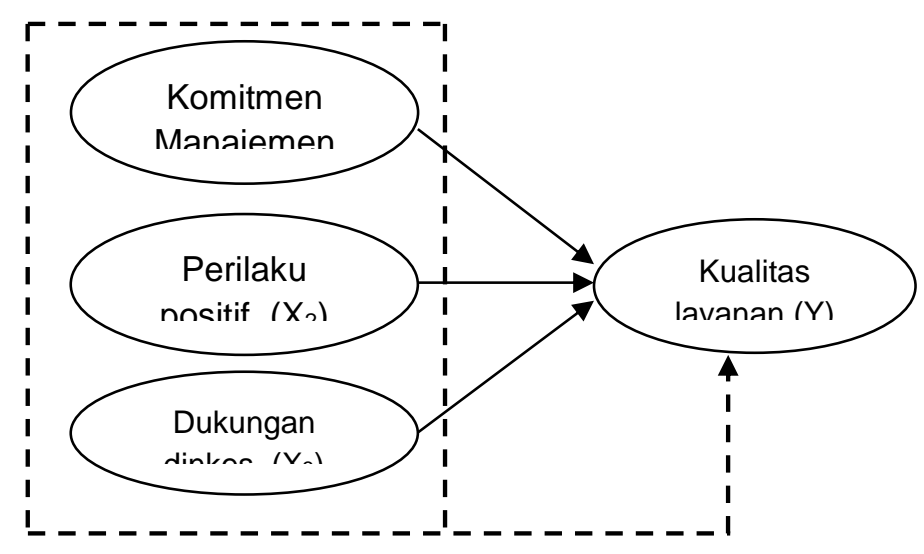

\subsection{Hipotesis Penelitian}

Adapun rumusan hipotesis (dugaan sementara) dalam penelitian ini adalah sebagai berikut :

H1 Komitmen manajemen, perilaku positif tenaga kesehatan dan dukungan Dinkes berpengaruh signfikan secara simultan terhadap kualitas layanan pada UPTD Puskesmas di Kabupaten Barito Selatan Provinsi Kalimantan Tengah.

H2 Komitmen manajemen, perilaku positif tenaga kesehatan dan dukungan Dinkes berpengaruh signfikan secara parsial terhadap kualitas layanan pada UPTD Puskesmas di Kabupaten Barito Selatan Provinsi Kalimantan Tengah.

H3 Komitmen manajemen berpengaruh dominan terhadap kualitas layanan pada UPTD Puskesmas di Kabupaten Barito Selatan Provinsi Kalimantan Tengah.

\section{BAB IV}

\section{METODE PENELITIAN}

\subsection{RancanganPenelitian}

Jenis penelitian yang digunakan dalam penelitian ini adalah kuantitatif. Sugiyono (2009:19) menyatakan bahwa penelitian kuantitatif adalah suatu metode penelitian yang bersifat induktif, objektif dan ilmiah dimana data yang di peroleh berupa angka-angka atau pernyataan-pernyataan yang dinilai, dan dianalisis dengan analisis statistik. Penelitian ini bertolak dari suatu teori yang kemudian diteliti, dihasilkan data, kemudian dibahas dan diambil kesimpulan. Pendekatan yang digunakan yaitu dengan cross sectional yaitu pengukuran variabel bebas dan terikat dilakukan sekali waktu pada satu saat. Penelitian ini bertujuan menganalisis komitmen manajemen, perilaku positip tenaga kesehatan, dan dukungan dinkes yang berpengaruh terhadap kualitas layanan pada puskesmas di Kabupaten Barito Selatan Provinsi Kalimantan Tengah periode tahun 2021.

\subsection{Definisi Operasional Variabel}

Adapun variabel-variabel yang dikumpulkan dalam penelitian ini adalah sebagai berikut:

1. Komitmen manajemen $\left(\mathrm{X}_{1}\right)$ adalah prasyarat penting bagi keberhasilan manajemen untuk peningkatan kualitas dan mutu organisasi serta pendorong untuk memotivasi karyawan agar berupaya meningkatkan kualitas proses yang berkesinambungan, dengan tujuan membantu mengatasi kekurangan dalam pelaksanaan suatu tugas atau proyek tertentu. Selian itu komitmen manajemen juga harus terlibat langsung dan mempertahankan kinerja untuk mencapai tujuan yang diharapkan.

2. Perilaku positif tenaga kesehatan $\left(\mathrm{X}_{2}\right)$ adalah perilaku seseorang yang cenderng bermanfaat baik bagi diri sendiri dan orang lain selain itu juga perilaku yang sesuai dengan nilai dan norma sosial yang berlaku dalam masyarakat. 
3. Dukungan Dinkes $\left(\mathrm{X}_{3}\right)$ adalah suatu aktivitas dan kegiatan yang diberikan Dinas Kesehatan kepada instansi kesehatan baik itu rumah sakit maupun puskesmas baik itu dalam bentuk kebijakan, fasilitas maupun hal lain yang dapat menunjang kelancaran dan keberhasilan institusi kesehatan dalam menigkatan masyarakat yang sehat.

4. Kualitas layanan (Y) adalah serangkaian kegiatan, karena ia merupakan proses. Sebagai proses, layanan berlangsung secara rutin dan berkesinambungan meliputi seluruh kehidupan organisasi dalam masyarakat.

\subsection{Jenis dan Sumber Data}

\subsubsection{Jenis Data}

Adapun jenis data dalam penelitian ini yang penulis ambil, yaitu sebagai berikut:

1. Data kualitatif, yaitu berupa data atau informasi yang tidak berbentuk angka. Penulis mengangkat data tersebut dari hasil wawancara dengan pihak instansi, yakni berupa data tentang sejarah instansi, struktur organisasi, bidang operasional.

2. Data kuantitatif yaitu data yang berbentuk angka, yang diangkat dari dokumen instansi dalam hal ini tentang data jumlah tenaga kesehatan data tabulasi dan data lain yang berhubungan dengan penelitiaan.

\subsubsection{Sumber Data}

Sumber data dalam penelitian ini terdiri dari sumber data primer dan sumber data sekunder:

1. Data Primer merupakan diperoleh secara langsung dari sumber asli secara khusus di kumpulkan oleh peneliti untuk menjawab pertanyaan yang diajukan melalui daftar pertanyaan.

2. Data Sekunder merupakan data yang diperoleh secara tidak langsung melalui media perantara seperti informasi dan publikasi atau laporan historis yang telah tersusun dalam dokumen/arsip.

\subsection{Populasi dan Sampel}

\subsubsection{Populasi}

Populasi dari penelitian ini adalah tenaga kesehatan di UPTD Puskesmas di Kabupaten Barito Selatan Provinsi Kalimantan Tengah yag berjumlah 685 orang.

\subsubsection{Sampel}

Sampel dalam penelitian ini adalah sebanyak 87 orang responden.

\subsection{Teknik Pengumpulan Data}

1. Observasi, yaitu pengumpulan data melalui pengamatan secara umum pada UPTD Puskesmas di Kabupaten Barito Selatan
Provinsi Kalimantan Tengah sebagai dasar untuk mengindentifikasi permasalahan yang akan dibahas.

2. Wawancara, yaitu mengumpulkan data dengan mengadakan tanya jawab secara lisan dengan pihak tenaga kesehatan UPTD Puskesmas di Kabupaten Barito Selatan Provinsi Kalimantan Tengah pada waktu yang telah ditentukan.

3. Dokumentasi, yaitu teknik pengumpulan data melalui pencatatan dan pengumpulan data instansi yang berkaitan dengan permasalahan yang akan dibahas.

4. Kuisioner, yaitu pengumpulan data dengan cara membagikan daftar pertanyaan secara tertulis kepada tenaga kesehatan untuk memperoleh data primer yang diperlukan dalam penyusunan tesis ini.

\subsection{Teknik Analisis Data}

Dalam penelitian ini teknik pengolahan data yang akan dilakukan oleh penulis adalah dengan menggunakan kuantitatif yakni analisis bertujuan untuk membuat diskripsi, gambaran atau lukisan secara sistematis, faktual dan akurat mengenai fakta-fakta, sifat-sifat serta hubungan antar fenomena yang diselidiki secara terperinci untuk menghasilkan rekomendasi untuk keperluan di masa yang akan datang. Berdasarkan hal tersebut, alat uji yang digunakan adalah:

\subsubsection{Uji Validitas Dan Reliabilitas}

1. Uji Validitas,pengambilan keputusan untuk validitas instrumen pertanyaan adalah sebagai berikut: Jika rhitung positif dan rhitung > rtabel maka instrument tersebut valid. Jika rtabel negative dan rhitung < rtabel maka instrument tersebut tidak valid.

2. Uji Reliabilitas, keputusan dikatakan reliabel jika Cronbach's alpa> 0,6 sebaliknya dikatakan tidak reliabel jika Cronbach's alpa $<0,6$.

\subsubsection{Uji Asumsi Klasik}

Asumsi klasik yang dimaksud terdiri dari :

1. Uji Multikolienearitas dapat diketahui dengan memeriksa nilai VIF (variance inflation factor) yang merupakan unsur diagonal invers matrik korelasi sederhana antara perubahan bebas. Apabila beberapa nilai VIF lebih dari 10 maka multikolienearitas adalah sebuah masalah (Solimun, 2013:35).

2. Uji Heteroskedastisitas, jika diagram pencar yang membentuk pola-pola tertentu yang teratur maka regresi mengalami gangguan heteroskedastisitas dan jika diagram pencar tidak membentuk pola atau acak maka regresi tidak mengalami gangguan heteroskedastisitas. 
3. Uji Normalitas (kenormalan) dengan cara membuat plot antara skor normal dengan data observasi dan melihat penyebaran data (titik) pada sumbu diagonal dari grafik. Bilamana hasil plot menujukkan pola garis lurus mendekati $45^{\circ}$ asumsi normalitas terpenuhi.

4. Uji Autokorelasi, untuk mendeteksi ada/tidak adanya autokorelasi pada penelitian ini menggunakan uji Durbin-Watson (DW test) yaitu nilai DW $<1,10$; ada autokorelasi, nilai DW anatar 1,10 s.d 1,54; tanpa kesimpulan, nilai DW antara 1,55 s.d 2,45 ; tidak ada autokorelasi, nilai DW antara 2,46 s.d 2,91 ; tanpa kesimpulan dan nilai DW > 2,91; ada autokorelasi. (Solimun, 2013:68).

\subsubsection{Uji Hipotesis}

\section{Analisis Regresi Berganda}

Adapun rumus dari regresi linier berganda adalah sebagai berkut:

$$
\mathbf{Y}=\mathbf{a}+\boldsymbol{\beta 1} \mathbf{. X 1}+\boldsymbol{\beta 2 . X 2}+\boldsymbol{\beta 3 . X 3}+\varepsilon
$$

\section{Pengujian Hipotesis}

a. Uji Simultan (Uji F) kreterianya Jika Fhitung < Ftabel berarti $\mathrm{H}_{\mathrm{A}}$ ditolak dan Jika Fhitung > Ftabel berarti $\mathrm{H}_{\mathrm{A}}$ diterima.

b. Uji Parsial (Uji T) kreterianya Jika thitung < ttabel berarti $\mathrm{H}_{\mathrm{A}}$ ditolakdan Jika thitung $>$ ttabel berarti $\mathrm{H}_{\mathrm{A}}$ diterima.

b. Uji Variabel Dominan Untuk mengkaji variabel yang dominan digunakan indikator koefisien beta standardized dari variabelvariabel dari model regresi.

\section{BAB V}

\section{ANALISIS HASIL PENELITIAN DAN} PEMBAHASAN

\subsection{Analisis Hasil Penelitian}

\subsubsection{Pengujian Instrumen Penelitian}

\section{Uji Validitas}

Adapun hasil uji validitas dalam penelitian ini adalah sebagai berikut:

\section{Tabel 5.9}

Uji Validitas

\section{Variabel Komitmen Manajemen (X1)}

\begin{tabular}{|c|c|c|}
\hline $\begin{array}{c}\text { Indikator } \\
\text { Pernyataan }\end{array}$ & $\begin{array}{c}\text { Hasil Uji validitas } \\
\text { (rhitung) }\end{array}$ & $\begin{array}{c}\text { Data Baku } \\
\text { (rtabel) }\end{array}$ \\
\hline X1.1 & $0,717(* *)$ & 0,211 \\
X1.2 & $0,741(* *)$ & 0,211 \\
X1.3 & $0,715(* *)$ & 0,211 \\
X1.4 & $0,809(* *)$ & 0,211 \\
X1.5 & $0,812(* *)$ & 0,211 \\
X1.6 & $0,587(* *)$ & 0,211 \\
X1.7 & $0,534(* *)$ & 0,211 \\
X1.8 & $0,535(* *)$ & 0,211 \\
\hline
\end{tabular}

Sumber : Data spss diolah
Hasil Uji validitas variabel komitmen manajemen (X1) terlihat nilai rhitungnya lebih besar rtabel, dengan demikian indikator pernyataan komitmen manajemen, valid datanya.

\section{Tabel 5.10}

Uji Validitas

Perilaku Positip Tenaga Kesehatan (X2)

\begin{tabular}{|c|c|c|}
\hline $\begin{array}{c}\text { Indikator } \\
\text { Pernyataan }\end{array}$ & $\begin{array}{c}\text { Hasil Uji validitas } \\
\text { (rhitung) }\end{array}$ & $\begin{array}{c}\text { Data Baku } \\
\text { (rtabel) }\end{array}$ \\
\hline X2.1 & $0,647(* *)$ & 0,211 \\
X2.2 & $0,741(* *)$ & 0,211 \\
X2.3 & $0,777(* *)$ & 0,211 \\
X2.4 & $0,834(* *)$ & 0,211 \\
X2.5 & $0,805(* *)$ & 0,211 \\
X2.6 & $0,720(* *)$ & 0,211 \\
X2.7 & $0,744(* *)$ & 0,211 \\
X2.8 & $0,625(* *)$ & 0,211 \\
\hline
\end{tabular}

Sumber : Data spss diolah

Hasil Uji validitas variabel perilaku positip tenaga kesehatan (X2) terlihat nilai rhitungnya lebih besar rtabel, dengan demikian indikator pernyataan perilaku positip tenaga kesehatan, valid datanya.

Tabel 5.11

Uji Validitas

Variabel Dukungan Dinkes (X3)

\begin{tabular}{|c|c|c|}
\hline $\begin{array}{c}\text { Indikator } \\
\text { Pernyataan }\end{array}$ & $\begin{array}{c}\text { Hasil Uji validitas } \\
\text { (rhitung) }\end{array}$ & $\begin{array}{c}\text { Data Baku } \\
\text { (rtabel) }\end{array}$ \\
\hline X3.1 & $0,762(* *)$ & 0,211 \\
X3.2 & $0,800(* *)$ & 0,211 \\
X3.3 & $0,767(* *)$ & 0,211 \\
X3.4 & $0,822(* *)$ & 0,211 \\
X3.5 & $0,813(* *)$ & 0,211 \\
X3.6 & $0,841(* *)$ & 0,211 \\
X3.7 & $0,685(* *)$ & 0,211 \\
\hline
\end{tabular}

Sumber : Data spss diolah

Hasil Uji validitas variabel dukungan dinkes (X3) terlihat nilai rhitungnya lebih besar rtabel, dengan demikian indikator pernyataan dukungan dinkes, valid datanya.

Tabel 5.12

Uji Validitas

Variabel Kualitas Pelayanan (Y)

\begin{tabular}{|c|c|c|}
\hline $\begin{array}{c}\text { Indikator } \\
\text { Pernyataan }\end{array}$ & $\begin{array}{c}\text { Hasil Uji validitas } \\
\text { (rhitung) }\end{array}$ & $\begin{array}{c}\text { Data Baku } \\
\text { (rtabel) }\end{array}$ \\
\hline Y1.1 & $0,622(* *)$ & 0,211 \\
Y1.2 & $0,720(* *)$ & 0,211 \\
Y1.3 & $0,516(* *)$ & 0,211 \\
Y1.4 & $0,785(* *)$ & 0,211 \\
Y1.5 & $0,760(* *)$ & 0,211 \\
Y1.6 & $0,576(* *)$ & 0,211 \\
Y1.7 & $0,590(* *)$ & 0,211 \\
Y1.8 & $0,546(* *)$ & 0,211 \\
Y1.9 & $0,631(* *)$ & 0,211 \\
\hline
\end{tabular}




\begin{tabular}{|l|c|c|}
\hline Y1.10 & $0,607(* *)$ & 0,211 \\
\hline
\end{tabular}

Hasil Uji validitas variabel kualitas pelayanan (Y) terlihat nilai rhitungnya lebih besar rtabel, dengan demikian indikator pernyataan kualitas pelayanan, valid datanya.

\section{Uji Reliabilitas}

Berikut rekapitulasi dari hasil uji reliabilitas instrument, sebagai berikut;

Tabel 5.13

Hasil Uji Reliabilitas

\begin{tabular}{|l|c|}
\hline \multicolumn{1}{|c|}{ Variabel Penelitian } & $\begin{array}{c}\text { Hasil Uji } \\
\text { Reliabilitas } \\
\text { Cronbach Alpha }\end{array}$ \\
\hline Komitmen manajemen (X1) & 0,755 \\
Perilaku positip (X2) & 0,779 \\
Dukungan dinkes (X3) & 0,791 \\
Kualitas pelayanan (Y) & 0,708 \\
\hline
\end{tabular}

Sumber: Data spss diolah

Hasil uji reliabilitas untuk semua variabel bebas diketahui nilai Cronbach $\mathrm{A}_{\text {lpha }}$ lebih besar dari nilai baku, sehigga dengan demikian dapat dikatakan semua variabel bebas datanya reliabel.

\subsubsection{Uji Asumsi Klasik}

\section{Uji Multikolinieritas struktur}

Analisis uji asumsi klasik dengan alat uji multikolinieritas, yaitu:

Tabel 5.14

Hasil Uji Multikolinieritas

\begin{tabular}{|l|c|c|}
\hline \multicolumn{1}{|c|}{ Variabel Bebas } & Tolerance & VIF \\
\hline $\begin{array}{l}\text { Komitmen } \\
\text { manajemen (X1) }\end{array}$ & 0,995 & 1,137 \\
\hline $\begin{array}{l}\text { Perilaku positip } \\
\text { tenaga kesehatan } \\
\text { (X2) }\end{array}$ & 0,983 & 1,113 \\
\hline $\begin{array}{l}\text { Dukungan dinkes } \\
(\mathrm{X} 3)\end{array}$ & 0,978 & 1,098 \\
\hline
\end{tabular}

Sumber: Data spss diolah

Hasil ui asumsi klasik pertama melalui uji multikolinieritas diketahui nilai tolerance mendekati 1 dan nilai variance inflation factor (VIF) memiliki nilai VIF kurang dari 10, dengan demikian uji ini data normal.

\section{Uji Heteroskedastisitas}

Selanjutnya adalah uji asumsi klasik kedua, yaitu uji heteroskedastisitas, uji ini menilai atau mengambil asumsi dari grafik scatterplot pada hasil uji regresi. Hasil uji grafik scatterplots di atas ini terlihat titik-titik menyebar secara acak serta tersebar baik di atas maupun di bawah angka 0 pada sumbu Y. Disimpulkan bahwa tidak terjadi heteroskedastisitas pada model regresi, atau data normal.

\section{Uji Normalitas (kenormalan)}

Uji asumsi klasik selanutnya adalah uji normalitas, uji ini cara penilaiannya atau didasar dengan mendeteksi graifk Plot of Regression. Hasil analisis dari uji ini terlihat titik penyebaran disekitar garis diagonal / menunjukkan pola garis lurus mendekati sudut $45^{\circ}$, maka di dapat bahwa semua data berdistribusi normal, sehingga asumsi normalitas terpenuhiatau data normal.

\section{Uji Autokorelasi}

Adapun hasil uji autokorelasi dalam penelitian ini adalah nilai uji Durbin Watson (DW) sebesar 2,392 masuk dalam nilai DW antara 1,55 s.d 2,45 (mendekati 2), dapat disimpulkan bahwa tidak terdapat otokorelasi antara variabel bebas dengan variabel terikat.

\subsubsection{Uji Regresi Linier Berganda}

Langkah selanjutnya adalah menguji hipotesis penelitian, sebelum menguji hipotesis maka dapat disusun terlebih dahulu persamaan uji regresi, berikut ini:

Tabel 5.16

\section{Hasil Uji regresi linier Berganda} Coefficients(a)

\begin{tabular}{|c|c|c|c|c|c|}
\hline & \multicolumn{2}{|c|}{$\begin{array}{c}\text { Unstandardized } \\
\text { Coefficients }\end{array}$} & \multirow{2}{*}{$\begin{array}{c}\text { Standardized } \\
\text { Coefficients } \\
\text { Beta } \\
\end{array}$} & \multirow[b]{2}{*}{$t$} & \multirow[b]{2}{*}{ Sig. } \\
\hline & B & $\begin{array}{l}\text { Std. } \\
\text { Error }\end{array}$ & & & \\
\hline (Constant) & 21,260 & 3,726 & & 5,707 &, 000 \\
\hline Komitmen & & & & & \\
\hline $\begin{array}{l}\text { Manajemen } \\
\text { (X1) }\end{array}$ & 745, & 110 & ,743 & 6,772 & ,000 \\
\hline $\begin{array}{l}\text { Perilaku Positip } \\
\text { Tenaga } \\
\text { Kesehatan (X2) }\end{array}$ & 701, & 116, & 669, & 6,043 & ,001 \\
\hline $\begin{array}{l}\text { Dukungan } \\
\text { Dinkes (X3) }\end{array}$ & 666 & , 123 & ,664 & 5,414 &, 002 \\
\hline
\end{tabular}

a Dependent Variable: Kulitas Pelayanan (Y)

Sumber : Data spss diolah

\subsubsection{Uji Hipotesis Penelitian}

Selanjutnya untuk mengevaluasi dan menguji hipotesis secara simultan, yaitu:

\section{Uji hipotesis pertama (Uji Simultan)}

Komitmen manajemen, perilaku positif tenaga kesehatan dan dukungan Dinkes berpengaruh signfikan secara simultan terhadap kualitas layanan pada UPTD Puskesmas di Kabupaten Barito Selatan Provinsi Kalimantan Tengah Uji F (simultan) ini digunakan data Fhitung dengan data Ftabel, untuk mengetahui Fhitung dapat dilihat dari tabel Anova, berikut dapat disajikan data tabelANOVA, sebagai berikut:

Tabel 5.17

ANOVA(b)

\begin{tabular}{|l|c|c|c|c|c|}
\hline & $\begin{array}{c}\text { Sum of } \\
\text { Squares }\end{array}$ & Df & $\begin{array}{c}\text { Mean } \\
\text { Square }\end{array}$ & F & Sig. \\
\hline Regression & 87,657 & 3 & 132,987 & 8,930 & ,000(a)
\end{tabular}




\begin{tabular}{|l|r|r|r|l|l|} 
Residual & 27,488 & 84 & 30,847 & & \\
Total & 115,145 & 87 & & & \\
\hline
\end{tabular}

Selanjutnya dapat dianalisis nilai Fhitung $8.930>$ Ftabel 2,715, kesimpulannya dapat dinyatakan bahwa komitmen manajemen, perilaku positif tenaga kesehatan dan dukungan Dinkes berpengaruh signfikan secara simultan terhadap kualitas layanan pada UPTD Puskesmas di Kabupaten Barito Selatan Provinsi Kalimantan Tengah. Kemudian untuk melihat seberapa besar pengaruh secara simultan tersebut, maka dapat dilihat melalui uji keofesien diterminasi, sebagai berikut

Tabel 5.18

Model Summary(b)

\begin{tabular}{|l|r|r|r|c|}
\hline $\begin{array}{l}\text { Mode } \\
1\end{array}$ & $\mathrm{R}$ & $\begin{array}{c}\text { Squar } \\
\mathrm{e}\end{array}$ & $\begin{array}{c}\text { Adjust } \\
\text { ed R } \\
\text { Square }\end{array}$ & $\begin{array}{c}\text { Error of } \\
\text { the } \\
\text { Estimat } \\
\mathrm{e}\end{array}$ \\
\hline 1 &, $817(\mathrm{a}$ &, 761 &, 704 & 15,554 \\
\hline
\end{tabular}

Berdasarkan tabel Model Summary(b) tersebut dapat dilihat nilai $R$ Square sebesar 0,761 disini berarti $76,1 \%$ yang mana dapat diartikan variabel komitmen manajemen, perilaku positif tenaga kesehatan dan dukungan Dinkes berpengaruh terhadap kualitas layanan sebesar $76,1 \%$, sedangkan sisanya sebesar $23,9 \%$ atau (100\% $76,1 \%$ ) dipengaruhi oleh variabel lain.

\section{Uji Hipotesis Kedua (Uji Parsial)}

Komitmen manajemen, perilaku positif tenaga kesehatan dan dukungan Dinkes berpengaruh signfikan secara parsial terhadap kualitas layanan pada UPTD Puskesmas di Kabupaten Barito Selatan Provinsi Kalimantan Tengah.

a. Hasil uji thitung untuk variabel komitmen manajemen (X1), sebagai berikut:

Kemudian berdasarkan data pada tabel tersebut diketahui data thitung hasil dari pengolahan regresi yaitu sebesar 6,772 dengan tingkat signifikasi 0,000 . Berdasarkan hal itulah maka dapat diuji secara parsial untuk variabel komitmen manajemen terhadap kualitas pelayanan, yakni didasarkan pada perbandingan antara thitung 6,772 dan ttabel 1,654 dan mempunyai pengaruh signifikan yang mana nilai probabilitas sebesar $p<0,05$ yaitu $0,000<$ 0,05 yang berarti terdapat pengaruh yang signifikan antara variabel komitmen manajemen dengan variabel terikat kualitas pelayanan. Besarnya pengaruh dari variabel komiten manajemen terhadap kualitas pelayanan dapat diketahui dari Standardized Coefficients Beta 0,743 yang berarti variabel komiten manajemen memberikan pengaruh terhadap kualitas pelayanan sebesar $74,3 \%$.

b. Hasil uji thitung untuk variabel perilaku positip tenaga kesehatan (X2), sebagai berikut:

Berdasarkan tabel tersebut diketahui data thitung hasil dari pengolahan regresi yaitu sebesar 6,043 dengan tingkat signifikasi 0,01 . Berdasarkan hal itulah maka dapat diuji secara parsial untuk variabel perilaku positip tenaga kesehatan terhadap kualitas pelayanan, yakni didasarkan pada perbandingan antara thitung 6,043 dan ttabel 1,654 dengan nilai signifikansi $p<0,05$ yaitu 0,001 > 0,05 , berarti terdapat pengaruh signifikan variabel perilaku positip tenaga kesehatan terhadap kualitas pelayanan. Besarnya pengaruh dari variabel perilaku positip tenaga kesehatan terhadap kualitas pelayanan dapat diketahui dari Standardized Coefficients Beta 0,669 yang berarti variabel perilaku positip tenaga kesehatan memberikan pengaruh terhadap kualitas pelayanan sebesar $66,9 \%$.

c. Hasil uji thitung untuk variabel dukungan dinkes (X3), sebagai berikut:

Berdasarkan tabel tersebut diketahui data thitung hasil dari pengolahan regresi yaitu sebesar 5,411 dengan tingkat signifikasi 0,002. Berdasarkan hal itulah maka dapat diuji secara parsial untuk variabel dukungan dinkes terhadap kuailtas pelayanan, yakni didasarkan pada perbandingan antara thitung 5,414 dan ttabel 1,654 dan mempunyai pengaruh signifikan yang mana nilai probabilitas sebesar $p<0,05$ yaitu $0,002<0,05$ yang berarti terdapat pengaruh signifikan antara variabel dukungan dinkes dengan variabel terikat kualitas pelayanan. Besarnya pengaruh dari variabel dukungan dinkes terhadap kualitas pelayanan (Y) dapat diketahui dari Standardized Coefficients Beta 0,664 yang berarti variabel dukungan dinkes memberikan pengaruh terhadap kualitas pelayanan sebesar $66,4 \%$.

\section{Hipotesi Ketiga (Uji Dominan)}

Komitmen manajemen berpengaruh dominan terhadap kualitas layanan pada UPTD Puskesmas di Kabupaten Barito Selatan Provinsi Kalimantan Tengah. Berdasarkan data pada tabel tersebut dapat dianalisis akan hasil pengujian hipotesis ke tiga menunjukkan bahwa variabel bebas yang mempengaruhi variabel terikat secara dominan adalah komitmen manajemen karena mempunyai nilai Standardized Coefficients Beta paling tinggi, yaitu sebesar 0,743 bila dibanding dengan variabel bebas lainnya, maka dapat disimpulkan bahwa hipotesis ke tiga variabel yang dominan 
mempengaruhi kualitas pelayanan adalah variabel komitmen manajemen.

\subsection{Pembahasan}

1. Komitmen manajemen, perilaku positif tenaga kesehatan dan dukungan Dinkes berpengaruh signfikan secara simultan terhadap kualitas layanan pada UPTD Puskesmas di Kabupaten Barito Selatan Provinsi Kalimantan Tengah. Dinas Kesehatan (Dinkes) juga diperlukan dalam mendorong kinerja pihak puskesmas dalam memberikan pelayanan, baik melalui pengawasan secara langsung, melakukan evaluasi pelayanan yang diberikan puskesmas dan memberikan penialain dan penghargaan kepada puskesmas yang berprestasi dalam aktifitas pelayanan.

2. Komitmen manajemen, perilaku positif tenaga kesehatan dan dukungan Dinkes berpengaruh signfikan secara parsial terhadap kualitas layanan pada UPTD Puskesmas di Kabupaten Barito Selatan Provinsi Kalimantan Tengah.

Hasi uji hipotesis kedua diketahui bahwa komitmen manajemen, perilaku positif tenaga kesehatan dan dukungan Dinkes berpengaruh signfikan secara parsial terhadap kualitas layanan pada UPTD Puskesmas di Kabupaten Barito Selatan Provinsi Kalimantan Tengah, sejalan dengan hasl penelitian tersebut, maka hendakanya pihak Puskesmas di Kabupaten Barito Selatan Provinsi Kalimantan Tengah dapat lebih meningkatakan kembali akan komiten manajemen puskesmas, perilaku positip tenaga kesehatan di puskesmas dan dukungan Dinkes.

3. Komitmen manajemen berpengaruh dominan terhadap kualitas layanan pada UPTD Puskesmas di Kabupaten Barito Selatan Provinsi Kalimantan Tengah.

Hendaknya pihak UPT Puskesmas di Kabupaten Barito Selatan Provinsi Kalimantan Tengah, perlu memperhatikan dan meningkatkan kembali akan fungsi dan peran dari manajemen dalam mengelola kualitas pelayanan dengan cara:

a. Selalu berusaha meningkatkan aktivitas operasional selalu beroerintasi pada visi dan misi organisasi.

b. Selalu memberikan dan melakukan pengembangan serta pemberdayaan kompetensi dan pengadaan pelatihan yang berkualitas kepada segenap pegawai secara kontinyu.

c. Selau memberikan perhatian dan pemberian penghargaan berupa kompensasi kepada pegawai yang berprestasi dan berjasa bagi organisasi. d. Pemberian dukungan organisasional kepada pegawai dalam mengembankan diri dan karier.

e. Selalu memberikan dan menyediakan teknologi yang dapat memfasilitasi pemberian pelayanan prima kepada pasien.

f. Selalu mengevaluasi akan akuntabilitas kinerja anggota organisasi di seluruh tingkat organisasi.

g. Selalu mengevaluasi kebijakan selaras dengan nilai, sasaran, dan arahan strategis organisasi.

Selain itu guna memantapkan komitmen kerja pegawai, perlu juga UPTD Puskesmas di Kabupaten Barito Selatan Provinsi Kalimantan Tengah selalu mengadakan pengawasan dalam bekerja dan selalu mengevaluasi kinerja pegawainnya secara berkala agar efektifitas kerja dapat dicapai sesuai harapan.

\section{BAB VI \\ PENUTUP}

\subsection{Kesimpulan}

1. Hasi uji hipotesis pertama diketahui bahwa komitmen manajemen, perilaku positif tenaga kesehatan dan dukungan Dinkes berpengaruh signfikan secara simultan terhadap kualitas layanan pada UPTD Puskesmas di Kabupaten Barito Selatan Provinsi Kalimantan Tengah

2. Hasi uji hipotesis kedua diketahui bahwa komitmen manajemen, perilaku positif tenaga kesehatan dan dukungan Dinkes berpengaruh signfikan secara parsial terhadap kualitas layanan pada UPTD Puskesmas di Kabupaten Barito Selatan Provinsi Kalimantan Tengah

3. Hasi uji hipotesis ketiga diketahui bahwa komitmen manajemen, berpengaruh signfikan secara dominan terhadap kualitas layanan pada UPTD Puskesmas di Kabupaten Barito Selatan Provinsi Kalimantan Tengah

\subsection{Saran}

1. Hendaknya pimpinan puncak manajemen puskesmas dapat meningkatkan sistem manajemen kepatuhan dengan cara menyiapkan dan menjunjung nilai inti organisasi. Memastikan sumber daya yang ditugaskan bekerja optimal. Mengomunikasikan pentingnya sistem yang efektif. Mengarahkan dan mendukung orang-orang untuk berkontribusi terhadap efektivitas kerja. Menyiapkan dan memelihara mekanisme akuntabilitas, termasuk pelaporan tepat waktu terhadap masalah kepatuhan, termasuk ketidakpatuhan. Semua tingkat manajemen secara aktif menunjukkan komitmen untuk menyiapkan, mengembangkan, menerapkan, mengevaluasi, memelihara, dan memperbaiki sistem manajemen kepatuhan yang efektif dan 
responsif melalui tindakan dan keputusan. Sumber daya dialokasikan untuk menyiapkan, mengembangkan, menerapkan, mengevaluasi, memelihara, dan memperbaiki budaya kepatuhan yang baik melalui aktivitas dan pelatihan yang menumbuhkan kesadaran dan organisasi menugaskan dan meminta akuntabilitas kepatuhan kepada manajemen di seluruh tingkat organisasi.

2. Hendaknya pimpinan/pihak manajemen puskesmas dapat meningkatkan perilaku teaga kesehatan dengan cara selalu berpikir positif, selalu semangat, selalu berdisiplin dalam bekerja, selalu berusaha memberikan yang terbaik dalam bekerja, selalu mempunyai motivasi kerja yang tinggi, mempunyai percaya diri yang baik dalam bekerja, selalu menjauhi hal-hal yang tidak baik dalam bekerja dan mempunyai loyalitas dan integritas terhadap bidang pekerjaan, hal ini dilakukan dengan memberikan diklat atau pelatihan yang kontinyu.

3. Hendaknya pimpinan/pihak manajemen Dinas Kesehatan dapat memberikan dukungan kepada pihak puskesmas dengan cara: peningkatan kualitas, keterjangkauan, dan pemerataan pelayanan kesehatan di fasilitas pelayanan kesehatan dasar dan rujukan terutama bagi keluarga miskin, kelompok rentan dan penduduk di daerah terpencil, perbatasan, rawan bencana dan konflik. Peningkatan kualitas dan kuantitas tenaga kesehatan terutama untuk pelayanan kesehatan di daerah terpencil, tertinggal, dan perbatasan. Peningkatan promosi kesehatan dan pemberdayaan masyarakat dalam perilaku hidup bersih dan sehat. Meningkatkan Pemerataan dan Keterjangkauan Pelayanan Kesehatan.

4. Hendaknya pihak UPT Puskesmas di Kabupaten Barito Selatan Provinsi Kalimantan Tengah, perlu memperhatikan dan meningkatkan kembali akan fungsi dan peran dari manajemen dalam mengelola kualitas pelayanan dengan cara selalu berusaha meningkatkan aktivitas operasional selalu beroerintasi pada visi dan misi organisasi. Selalu memberikan dan melakukan pengembangan serta pemberdayaan kompetensi dan pengadaan pelatihan yang berkualitas kepada segenap pegawai secara kontinyu. Selau memberikan perhatian dan pemberian penghargaan berupa kompensasi kepada pegawai yang berprestasi dan berjasa bagi organisasi. Pemberian dukungan organisasional kepada pegawai dalam mengembankan diri dan karier. Selalu memberikan dan menyediakan teknologi yang dapat memfasilitasi pemberian pelayanan prima kepada pasien. Selalu mengevaluasi akan akuntabilitas kinerja anggota organisasi di seluruh tingkat organisasi. Selalu mengevaluasi kebijakan selaras dengan nilai, sasaran, dan arahan strategis organisasi.

\section{DAFTAR PUSTAKA}

Abomaleh, A. \& Zahari. I. (2015). The Influence of Management Commitment to Service Quality on Employee Performance, and the Mediating Role of Employee Involvement. Journal of Advanced Social Research Vol. 5 No.4, April 2015, 05-13

Azrul Azwar, 2016, Manajemen Kesehatan, Media Pustaka, Surabaya

Alma. Buchari, 2012, Manajemen Pelayanan Publik, Erlangga, Jakarta

Ancok. Pahpahan, 2012, Manajemen Organisasi dan Perilaku Keorganisasian, Bumi Aksara, Jakarta

Dwi Sulastri, 2015, Pengaruh Komitmen Manajemen, Perilaku Positip Tenaga Kesehatan Dan Dukungan Dinkes Terhadap Kualitas Layanan Rumah Sakit Ratu Zaleha Martapura, Unlam, Banjarmasin

Darmawan, 2010, Perilaku SDM dan Keorganisasian, Liberty, Jakarta

Dimas. Sunarya, 2013, Komitmen Organisasi (Psikologi Industri Dan Organisasi), Fakultas Psikologi, Universitas Mercua Buana, Yogyakarta

Ekawati, 2015, Pengaruh Komitmen Manajemen, Perilaku Positif Tenaga Kesehatan Dan Dukungan Dinkes Terhadap Kualitas Layanan Rumah Sakit dr. Soetarto Yogyakarta, Politeknik Kesehatan Karya Husada, Yogyakarta

Ermina. Putri, 2011, Komitmen dan Kepuasan Kerja, Fakultas Psikologi, Universitas Mercua Buana, Yogyakarta

Firmansyah, 2010, Peningkatan Kinerja SDM melalui Motivasi, Disiplin, Lingkungan Kerja dan Komitmen, Rineka Cipta, Jakarta

Ghozali, 2011, Metode Peneitian dan Riset dengan Aplikasi SPSS, Rajawali Press, Jakarta

Hariyanti, 2015, Perilaku Individu dan Keorganisasian, Pustaka, Jakarta

Hadipranata, 2010, Kualitas Pelayanan Publik, Rineka Cipta, Jakarta 
Hardiansyah, 2011, Kualitas Pelayanan Publik, Rineka Cipta, Jakarta

Heriawan, 2012, Manajemen Kesehatan, Rineka Cipta, Jakarta

Hari. Darmono, 2013, Perilaku Keorganisasian, Erlangga, Jakarta

Irmin, S. 2011 Sikap Positif Karyawan Berprestasi: Self Improvement Series, Setia Media, Jakarta

Ikwanuddin, 2011, Psikologi Bisnis, Rineka Cipta, Jakarta

Kashmir, 2011, Konsep Pelayanan dan Kepuasan Pelanggan, Gramedia, Jakarta

Kepmenkes RI No. 128/Menkes/SK/II/2004 puskesmas, Jakarta

Lupiyoadi, 2010, Manajemen Pemasaran Jasa, PT. Remaja Rosdakarya. Bandung

Martoyo, 2012, Manajemen Sumber Daya Manusia, Jilid I, Rineka Cipta, Jakarta

Mariam, 2013, Perilaku Individu dan Organisasi, balai Pustaka, Jakarta

Muchtarman, Muchtar, 2012, Pelayanan Publik Yang Profesional, Liberty,Jakarta

Musa, 2011, Manajemen Kesehatan, PT. Rajawali Press, Jakarta

Mulia.Putri, 2012, Manajemen Kesehatan, Rineka Cipta, Jakarta

Mulia, 2012, Manajemen Pelayanan Publik, Bumi Aksara, Jakarta

Muchransyah, 2013, Pengaruh Komitmen Manajemen, Perilaku Positip Tenaga Kesehatan Dan Dukungan Dinkes Terhadap Kualitas Layanan RSUD Kabupaten Balangan, Unlam, Banjarmasin

Moekijat, 2011, Manajemen SDM, Balai Pustaka, Jakarta

Nimran. Umar, 2013, Manajemen SDM dan Perilaku Organisasi, MNS Publishing, Jakarta

Nadirsyah, 2011, Perilaku Keorganisasian (Organisasi Pemerintah), CV. Agung, Jakarta Notoatmojo, 2010, Pendidikan dan Perilaku Kesehatan, Rineka Cipta, Jakarta

Okviana Rini, 2015, Aturan Perilaku Pegawai Di Organisasi Publik, Rineka Cipta, Jakarta

Pemeritah RI Nomor 25 tahun 2000 tentang kewenangan propinsi sebagai daerah otonomi, Jakarta

Poerwonno, 2014, Manajemen SDM, Global, Surabaya

Pratisto, Arif, 2004, Cara Mudah Mengatasi Statistik dan Rancangan Percobaan dengan SPSS 12, PT Elex Media Komputindo Kelompok Gramedia, Jakarta
Rasyid. Abdul, 2012, Mutu dan Pelayanan, Pro Teknologi, Bandung

Rikwan. Akhyar, 2011, Perilaku Keorganisasian, Balai Pustaka, Jakarta

Rangkuti, 2012, Keorganisasian dan Manajemen SDM, Rineka Cipta, Jakarta

Royan Ruslan, 2010, Manajemen dan Keorganisasian, Pustaka Karyawa, Jakarta

Setyowati , 2010, Komitmen, Alfabeta, Bandung Simanjuntak, 2013, Manajemen Publik dan Kebijakan Publik, Rineka Cipta, Jakarta

Siregar, 2013, Manajemen Pelayanan Publik, Books, Jakarta

Stephen P. Robins, 2010, Perilaku Organisasi, KonsepKontroversi-Aplikasi, Edisi Bahasa Indonesia. Jakarta: PT. Prenhalindo.

Sami Setiawan, 2010, Manajemen Pelayanan Kesehatan dan Perawatan, Rajawali Pres Jakarta

Sugiarto, 2012, Perilaku dan Korganisasian, Rineka Cipta, Jakarta

Sunarto, 2016, Pengaruh Komitmen Manajemen, Perilaku Positif Tenaga Kesehatan Dan Dukungan Dinkes Terhadap Kualitas Layanan Rumah Sakit Elisabeth Semarang, Universitas Dipenegoro, Semarang

Soeminto, 2013, Perilaku dan Korganisasian, Edisi Revisi, Rineka Cipta, Jakarta

Sekaran, Uma, 2003, Reseach Method For Business (Skill Building, Approach), Third Edition, John Weiley and Sans Inc, America

Suharsimi, Arikunto, 1998, Prosedur Penelitian Suatu Pendekatan dan Praktek, Rineka Cipta, Jakarta

Singarimbun, Masri, 2001, Metode Penelitian Survey. PPSK. Yogyakarta:UGM.

Sugiyono, 1999, Metode Penelitian Admisnitrasi, Alfabeta, Bandung

Solimun, Pelatihan Metodologi dan Komputer Statistik, Seminar Dua Hari Tanggal 26-27 Nopember 2004 di Banjarmasin

Supranto, 1995, Ekonometrik, Buku Dua, Lembaga PEnerbit Fakultas Ekonomi Universitas Indonesia, Jakarta

Sopiah Evi, 2012, Psikologi Bisnis dan Komitmen Organisasi, Erlangga, Jakarta

Syarif.Darman, 2018, Komitmen Organisasi (Teori Dan Pendekatan Komitmen), Unhara Manajemen Press, Jakarta

Tjiptono, Fandy, 2011, Strategi Pemasaran Jasa, Penerbit Andi, Yogyakarta 
Tavitiyaman, P. 2010. The Effect of Management Commitment to Service Quality on Employees' Job Satisfaction and Prosocial Service Behaviors. Submitted Thesis to Faculty of the Graduate College of the Oklahoma State University.Business \& Management Journal Bunda Mulia Vol.3, No. 1, Maret 2010

Tjiptono, 2011, Manajemen Pelayanan Publik, Global Media, Jakarta

UU No. 34/2014 Tentang Otonomi Daerah, Jakarta Undang-Undang RI Nomor 22 tahun 1999 tentang pemerintah daerah, Jakarta

Undang-undang RI Nomor 23 tahun 1992 yang menyatakan bahwa pembangunan kesehatan, Jakarta

Undang-undang No. 36 Tahun 2009 tentang Kesehatan, Jakarta

Wawan, 2011, 2013, Manajemen Organisasi, Media Pustaka, Surabaya

Eka Wulandari, 2014, Pengaruh Perilaku Positip Tenaga Kesehatan Dan Dukungan Dinkes Terhadap Kualitas Layanan pada Dinas Koperasi Kota Surabaya, Universitas Merdeka Surabaya 